CLINICAL STUDY

\title{
Presence and significance of a R110W mutation in the DNA-binding domain of GCM2 gene in patients with isolated hypoparathyroidism and their family members
}

\author{
Neeraj Tomar ${ }^{1}$, Hema Bora ${ }^{2}$, Ratnakar Singh ${ }^{3}$, Nandita Gupta ${ }^{1}$, Punit Kaur $^{4}$, Shyam Singh Chauhan ${ }^{3}$, \\ Yagya Dutta Sharma ${ }^{2}$ and Ravinder Goswami ${ }^{1}$ \\ Departments of ${ }^{1}$ Endocrinology and Metabolism, ${ }^{2}$ Biotechnology, ${ }^{3}$ Biochemistry and ${ }^{4}$ Biophysics, All India Institute of Medical Sciences, \\ New Delhi 110029, India \\ (Correspondence should be addressed to R Goswami; Email: gosravinder@hotmail.com)
}

\begin{abstract}
Objective: Glial cells missing 2 (GCM2) gene encodes a parathyroid-specific transcription factor. We assessed GCM2 gene sequence in patients with isolated hypoparathyroidism (IH).

Design: Case-control study.

Methods: Complete DNA sequencing of the GCM2 gene including its exons, promoter, and $5^{\prime}$ and $3^{\prime}$ UTRs was performed in 24/101 patients with IH. PCR-restriction fragment length polymorphism was used to detect a novel R110W mutation in all $101 \mathrm{IH}$ patients and 655 healthy controls. Significance of the mutation was assessed by electrophoretic mobility shift assay (EMSA) and nuclear localization on transfection.

Results: A heterozygous R110W mutation was present in DNA-binding domain in 11/101 patients $(10.9 \%)$ and absent in 655 controls $\left(P<10^{-7}\right)$. Four of 13 nonaffected first-degree relatives for five of these index cases had R110W mutation. Four heterozygous single nucleotide polymorphisms were found in the $5^{\prime}$ region. One of the 11 patients with R110W also had T370M change in compound heterozygous form. Mutant R110W and T370M GCM2 proteins showed decreased binding with GCM recognition elements on EMSA indicating loss of function. Both wild-type and R110W mutant GCM2 proteins showed nuclear localization.

Conclusions: The present study indicates a significant association of R110W variant with IH. Absence of effect of heterozygous R110W mutation on DNA binding and presence of the same mutation in asymptomatic family members indicate that additional genetic (akin to T370M change) or nongenetic factors might contribute to the expression of diseases in IH. Alternatively, it is possible that association of R110W with IH could be due to linkage disequilibrium with the unidentified relevant genes in $\mathrm{IH}$.
\end{abstract}

European Journal of Endocrinology 162 407-421

\section{Introduction}

Hypoparathyroidism is a heterogeneous group of disorders characterized by tetany, cataract, basal ganglia calcification, hypocalcemia, hyperphosphatemia, and subnormal serum parathyroid hormone (PTH) (1-12). Recently, Dolores Shoback has classified its pathophysiologic mechanisms into three broad categories (13). These include i) destruction of parathyroid gland due to iatrogenic causes, metastasis, heavy metal infiltration, and organ-specific autoimmunity occurring in isolation or as part of autoimmune polyendocrine syndrome type 1 (APS-1); ii) impairment of PTH secretion as seen in hyper- and hypomagnesemia, activated mutations of the calcium-sensing receptor $(\mathrm{CaSR})$, or nondestructive activating CaSR autoantibodies; and iii) disorders (familial or sporadic) due to mutations of genes such as PTH, glial cells missing 2 (GCM2), HDR syndromes (GATA3), autoimmune regulator in APS-1, tubulin cofactor $\mathrm{E}$ in Kenny-Caffey and Sanjad-Sakati syndrome, 22q11.2 TBX-1 (DiGeorge syndrome), and mitochondrial gene defects in Kearn-Sayre syndrome (13).

Patients with isolated hypoparathyroidism (IH) also referred to as acquired or idiopathic hypoparathyroidism demonstrate the presence of CaSR autoantibodies with prevalence varying from 29 to $56 \%$ (10-12). However, they do not demonstrate increased risk of coexisting thyroid autoimmunity unlike in type-1 diabetes and premature ovarian failure (14). These facts along with reports of de novo mutations in the CaSR and PTH genes in a subset of IH indicate that later is a cluster of heterogeneous group of disorder (15-17). In our previous studies, the PTH and CaSR genes were 
sequenced in 49 and 33 patients with $\mathrm{IH}$ respectively $(18,19)$. PTH gene and its $3^{\prime}$ UTR were normal in all (18) and only one had a heterozygous Val621Met mutation in exon 7 of the CaSR gene (19). The latter was considered benign because the same mutation was also present in her asymptomatic mother and brother. Besides, there was no increased prevalence of autoimmunity-related single nucleotide polymorphisms (SNPs) in the CTLA-4 and PTPN22 genes in our earlier studies in patients with $\mathrm{IH}(20,21)$.

Recently, familial hypoparathyroidism has also been linked with mutations of GCM gene (22-27). The GCM gene encodes a glial cells-specific transcription factor in Drosophila (28) and its mammalian homologs, i.e. gcm 1 and gcm 2 (mouse) and GCM1 and GCM2 (humans) encode transcription factors necessary for the development of placenta and parathyroid glands in the fetus and adults respectively (29-31). The GCM2 gene located on chromosome 6p23-24 encodes a 506 amino acids protein with DNA-binding domain from 21 to 174 amino acids, and its response elements have been described in the CASR gene $(25,27,32)$.

Although there are six reports of GCM 2 gene analysis in patients with familial hypoparathyroidism, only two included a total of 20 patients with $\mathrm{IH}(22,25)$. GCM2 gene sequence was normal in them $(22,25)$. We report GCM2 gene sequence analysis in a large cohort of patients with $\mathrm{IH}(14,18-21)$ and report occurrence of a new R110W mutation and its functional significance.

\section{Materials and methods}

\section{Patients}

The study included 101 patients with IH attending the endocrine and metabolic clinics of All India Institute of Medical Sciences, Delhi, during 1998-2008 (14, 18-21). The criteria used to diagnose IH included the presence of hypocalcemia, hyperphosphatemia, and an inappropriately normal or subnormal level of serum-intact PTH (iPTH), normal renal function, and serum magnesium (2). Patients with post-surgical hypoparathyroidism were excluded. There was one sibling pair (brothers) in study cohort. None of the patients had clinical features of type 1 APS. Autoimmune adrenal involvement was excluded by demonstrating normal serum cortisol and plasma ACTH and the absence of adrenal cortical autoantibodies by indirect immunofluorescence (33). Serum ferritin levels measured to rule out hemochromatosis were normal in all (34).

Number of patients studied for complete GCM2 gene sequencing $(\mathbf{n}=\mathbf{2 4})$ The group of 101 patients with $\mathrm{IH}$ was arranged in ascending order of age. The first and last 12 patients (17 males) were selected for complete sequencing of the GCM2 gene, which included all its the five exons, intron-exon boundaries, and $5^{\prime}$ and $3^{\prime}$ UTRs. The $5^{\prime}$ upstream sequence up to -652 position from translation start site ATG included $5^{\prime}$ UTR of exon 1, promoter sequence, and binding sites for PAX1 and PAX9 transcription factors (25).

Following detection of a new mutation (R110W) in exon 2, PCR-restriction fragment length polymorphism (RFLP) analysis was performed in all the 101 patients. To determine the prevalence of SNPs in the $5^{\prime}$ UTR, DNA sequencing of this region was undertaken in all the remaining 77 patients with $\mathrm{IH}$. The $\mathrm{P} 1$ and $\mathrm{P} 2$ promoter regions of the CaSR gene $(-606$ to -323 and -300 to -90 from transcription start site at +1 , accession number AY116081-82) were also sequenced in all the 11 patients with R110W mutation, and in 10 IH patients without R110W mutation for analysis of GCM response elements in these promoters $(-451$ to -441 relative to transcription start site at +1 in $\mathrm{P} 1$ and -166 to -156 in P2) (27). Complete sequencing of all the GCM2 exons was performed in eight additional patients detected to have R110W mutation on PCR-RFLP analysis.

\section{Controls}

The controls included 655 apparently healthy North Indian volunteers including school teachers, students, and other staff who were previously enrolled for the assessment of vitamin D deficiency, thyroid autoimmunity, and relationship of vitamin D receptor (VDR) polymorphisms with bone mineral density (35). All the controls had normal serum total calcium and inorganic phosphorus values. None of them had subnormal serum iPTH levels (35). Identification and genotyping of R110W mutation were performed by PCR-RFLP analysis in all the 655 controls. DNA sequencing of the $5^{\prime}$ UTR of GCM 2 and the P1 and P 2 promoters of the CaSR gene was performed in a limited number of controls $(n=53$ and 10 respectively).

The local institutional ethics committee approved the study protocol including genotyping among the control group. Written consent was obtained from all the study subjects.

\section{Relatives}

Thirteen nonaffected first-degree family members of 5 of the 11 index patients with R110W mutation (Fig. 1) could be investigated for clinical and biochemical features of hypoparathyroidism. Sequencing of exon 2 of the GCM 2 gene and its $5^{\prime}$ and $3^{\prime}$ UTRs was performed in all the relatives. Complete sequencing of the GCM2 gene and promoters of the CaSR gene was also performed in four relatives detected to have R110W mutation. 
I

II

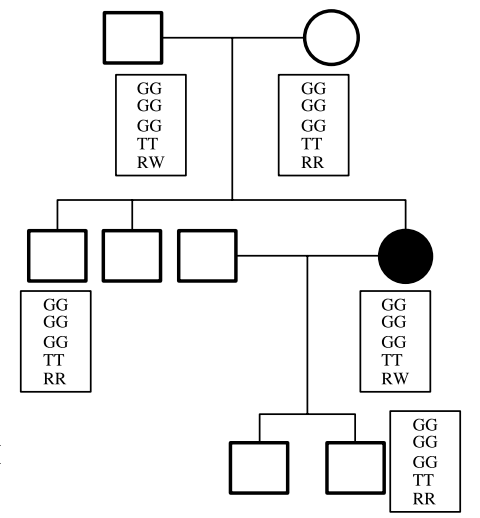

Family 1

I

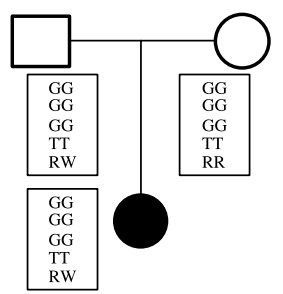

Family 3

I

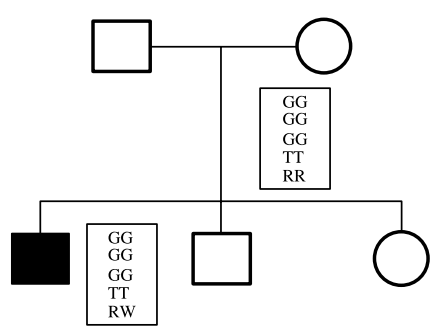

I

II

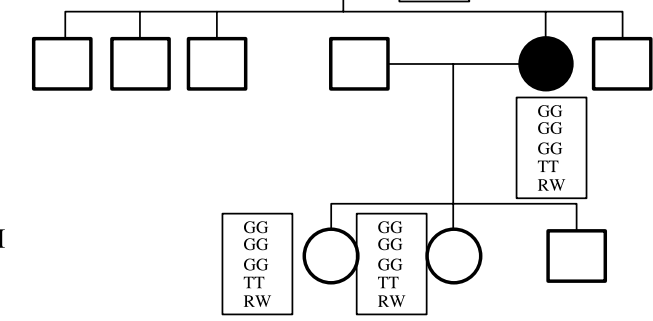

Family 2
I

II

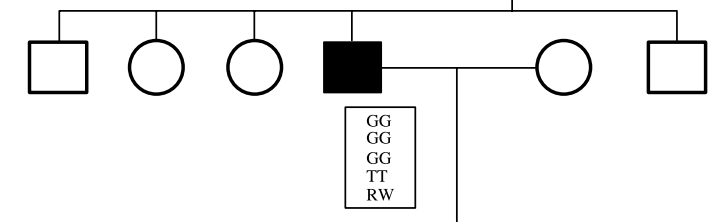

III

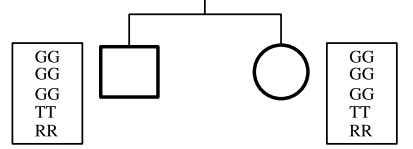

Family 4

Family 5

Figure 1 Pedigrees of 5 of the 11 index patients with R110W mutation whose 13 nonaffected first-degree family members were studied. The nucleotides (numbered from translation initiation site) observed at five variable sites in the GCM2 gene sequence are shown in rectangular box (from above to below). The possible alleles at these position were $-252 \mathrm{G} / \mathrm{T},-248 \mathrm{G} / \mathrm{C},-149 \mathrm{G} / \mathrm{A},-44 \mathrm{~T} / \mathrm{C}$, and C/T substitution at nucleotide 4711 in exon 2 leading to R110W mutation in codon 110. The nucleotide positions are according to GenBank accession no. NC_000006.

\section{Methods}

DNA sequence analysis Genomic DNA was extracted from the peripheral leukocytes (19). The first seven pairs of primers used to amplify GCM2 gene (Table 1) were the same as used by Thomée et al. (24), and their sequences and conditions for amplification were provided to us by one of the authors (Dr Abramowicz) on request. The primers used to amplify $3^{\prime}$ and $5^{\prime}$ UTRs of the GCM 2 gene and $\mathrm{P} 1$ and $\mathrm{P} 2$ promoter regions of CaSR gene were designed using software (biotools. umassmed.edu/bioapps/primer3_www.cgi). All the PCR were carried out in $40 \mu \mathrm{l}$ reaction volume using 100 ng genomic DNA (GenAmp 9700, Applied Biosystems, Foster City, CA, USA), and the amplified fragments were then excised from the agarose gel, purified
(Qiaex II gel extraction kit Qiagen Inc.), and directly sequenced by Big Dye v3.1 cycle sequencing chemistry on the ABI PRISM 310 Genetic Analyzer (Applied Biosystems). The nucleotide sequences were compared with the published sequence of human GCM2 gene (GenBank accession no. NT_007592) using Blastn algorithm (http://www.ncbi.nlm.nih.gov) and also deposited in the GenBank databases (accession no. FJ655842-49).

PCR-RFLP analysis The presence of $\mathrm{C}-\mathrm{T}$ substitution at nucleotide 4711 in exon 2 (GenBank accession no. NC_000006) created a restriction site for Hin1II enzyme (Fig. 2a). For the RFLP analysis, a 153 bp DNA fragment of exon 2 containing R110W mutation was amplified using forward (5'-gcaacaccaacaaccacaat-3') and 
Table 1 Primer sequences used to amplify various regions of the GCM2 gene, two promoters of the CaSR gene (P1 and P2), and for the PCR-restriction fragment length polymorphism (RFLP) analysis of R110W mutation.

\begin{tabular}{|c|c|c|c|c|c|}
\hline Serial no. & Site & Sense primer & Antisense primer & $\begin{array}{l}\text { Annealing } \\
\text { temperature } \\
\text { and time }\end{array}$ & $\begin{array}{l}\text { Amplicon } \\
\text { (bp) }\end{array}$ \\
\hline \multicolumn{6}{|c|}{ Glial cell missing B (GCM2) } \\
\hline $1^{\mathrm{a}}$ & Exon 1 & $5^{\prime}$-tccataaccattgtccccag-3' & $5^{\prime}$-tgtatggtccgtccgca-3' & $55^{\circ} \mathrm{C}, 1 \mathrm{~min}$ & 376 \\
\hline $2^{\mathrm{a}}$ & Exon 2 & $5^{\prime}$-ttggaatttgacgttactgg- $3^{\prime}$ & $5^{\prime}$-gagctgagattgcaccatt- $3^{\prime}$ & $55^{\circ} \mathrm{C}, 1 \mathrm{~min}$ & 516 \\
\hline $3^{a}$ & Exon 3 & $5^{\prime}$-cccgagcatgagttctttgt- $3^{\prime}$ & $5^{\prime}$-tcccaaggcacacgaca- $3^{\prime}$ & $55^{\circ} \mathrm{C}, 1 \mathrm{~min}$ & 292 \\
\hline $4^{\mathrm{a}}$ & Exon 4 & $5^{\prime}$-agatgttgggaaaggca-3' & $5^{\prime}$-ttttgttttaaggagaaggg- $3^{\prime}$ & $52^{\circ} \mathrm{C}, 1 \mathrm{~min}$ & 410 \\
\hline $5^{\mathrm{a}}$ & Exon $5 a$ & $5^{\prime}$-ttgtcattcagtcgttggta- $3^{\prime}$ & $5^{\prime}$-cagatgaacccagtctgtgt- $3^{\prime}$ & $53^{\circ} \mathrm{C}, 1 \mathrm{~min}$ & 553 \\
\hline $6^{\mathrm{a}}$ & Exon $5 b$ & $5^{\prime}$-tcaagcccatatcccac- $3^{\prime}$ & $5^{\prime}$-ctgcaattttcataggaggt- $3^{\prime}$ & $53^{\circ} \mathrm{C}, 1 \mathrm{~min}$ & 502 \\
\hline $7^{\mathrm{a}}$ & Exon $5 \mathrm{c}$ & $5^{\prime}$-atacagtgacagtgtgcgag- $3^{\prime}$ & $5^{\prime}$-acaaggtgaatctcccaac- $3^{\prime}$ & $56^{\circ} \mathrm{C}, 1 \mathrm{~min}$ & 422 \\
\hline 8 & $5^{\prime}$ UTR & $5^{\prime}$-gcgggcagatcgtcaggagttca- $3^{\prime}$ & $5^{\prime}$-cgttctccacccgaacggcagca- $3^{\prime}$ & $60^{\circ} \mathrm{C}, 30 \mathrm{~s}$ & 506 \\
\hline 9 & $5^{\prime}$ UTR & $5^{\prime}$-cctccgttcctgggactgtggtgga- $3^{\prime}$ & $5^{\prime}$-gagctgcatcccgtaggagcacacg- $3^{\prime}$ & $60^{\circ} \mathrm{C}, 30 \mathrm{~s}$ & 435 \\
\hline 10 & $3^{\prime}$ UTR & $5^{\prime}$-gcagtgtgcatgcaggcagga-3 & $5^{\prime}$-ggcagcctctagggatgtgaa- $3^{\prime}$ & $60^{\circ} \mathrm{C}, 30 \mathrm{~s}$ & 374 \\
\hline 11 & $3^{\prime}$ UTR & $5^{\prime}$-cacatccctagaggctgccaaa- $3^{\prime}$ & $5^{\prime}$-ggaaccgtaaagctgtatttcagca-3' & $60^{\circ} \mathrm{C}, 30 \mathrm{~s}$ & 407 \\
\hline 12 & R110W RFLP & $5^{\prime}$-gcaacaccaacaaccacaat- $3^{\prime}$ & $5^{\prime}$-tgtcctcactctgctgtttca-3' & $55^{\circ} \mathrm{C}, 30 \mathrm{~s}$ & 153 \\
\hline \multicolumn{6}{|c|}{ Calcium-sensing receptor gene promoter ( $\mathrm{CaSR})$} \\
\hline 13 & CaSR-P1 & $5^{\prime}$-agattgcagcctcattcgggttttg-3' & $5^{\prime}$-ccaagttctgcccatttggcttcct- $3^{\prime}$ & $60^{\circ} \mathrm{C}, 30 \mathrm{~s}$ & 284 \\
\hline 14 & CaSR-P2 & $5^{\prime}$-ggacagcgggaacaggatttgagag- $3^{\prime}$ & $5^{\prime}$-cccagttagtcccggttccttcacc- $3^{\prime}$ & $60^{\circ} \mathrm{C}, 30 \mathrm{~s}$ & 211 \\
\hline
\end{tabular}

For all PCR reactions: initial denaturation at $94^{\circ} \mathrm{C}$ for 6 min followed by 40 cycles of denaturation at $94{ }^{\circ} \mathrm{C}$ for $30 \mathrm{~s}$, annealing as shown in table, extension at $72^{\circ} \mathrm{C}$ for $30 \mathrm{~s}$, and final extension at $72^{\circ} \mathrm{C}$ for $7 \mathrm{~min}$.

aPrimers nos 1-7 have been described earlier by Thomée et al. (Ref. (24)).

reverse $\left(5^{\prime}\right.$-tgtcctcactctgctgtttca- $\left.3^{\prime}\right)$ primers and digested with 5 units of Hin 1 II enzyme at $37^{\circ} \mathrm{C}$ for $12 \mathrm{~h}$. The presence of heterozygous mutation resulted in 153, 130, and 23 bp fragments, which were resolved by $2.5 \%$ agarose gel electrophoresis (Fig. $2 b$ ).

\section{Assessment of intragenic deletion in GCM2 allele in subjects with R110 W mutation}

To assess the possibility of intragenic deletion within the other GCM2 allele in 11 patients with heterozygous R110W mutation, an $8.09 \mathrm{~kb}$ fragment of the GCM2 gene incorporating all the five exons and four intervening introns was amplified by long PCR enzyme mix (Cat no. K0181, Fermentas, Lithuania) and primers $5^{\prime}$-tccataaccattgtccccag- $3^{\prime}$ and $5^{\prime}$-acaaggtgaatctcccaac- $3^{\prime}$. Conditions for PCR amplification were: initial denaturation at $94{ }^{\circ} \mathrm{C}$ for $3 \mathrm{~min}$, followed by 22 cycles of denaturation at $94{ }^{\circ} \mathrm{C}$ for $20 \mathrm{~s}$, annealing at $55^{\circ} \mathrm{C}$ for $30 \mathrm{~s}$, extension at $68{ }^{\circ} \mathrm{C}$ for $7 \mathrm{~min}$, and final extension at $68{ }^{\circ} \mathrm{C}$ for $10 \mathrm{~min}$. The contribution of both the alleles in the $8.09 \mathrm{~kb}$ PCR product was confirmed by performing a RFLP analysis for R110W mutation in the $153 \mathrm{bp}$ product amplified using the $8.09 \mathrm{~kb}$ product as the template.

\section{Cloning, expression, and purification of wild-type and mutant GCM2 proteins}

Preparation of wild-type GCM2 clone A wild-type cDNA encoding full-length GCM2 protein was prepared from the RNA extracted from parathyroid adenoma tissue obtained after informed consent from a patient undergoing parathyroidectomy using the RNA-binding columns (Eppendorf AG-22331, Hamburg, Germany). The first strand of cDNA was synthesized using the random hexamers and M-MuLV RT (RevertAidH Minus, Fermentas). The sense $\left(5^{\prime}\right.$-agcgcgagcgagtCgACcagatgccg-3 $3^{\prime}$ ) and antisense (5'-tccetgcCtcGagcctgcatgcacac- $3^{\prime}$ ) primers were used to prepare double-stranded cDNA. The SalI and XhoI restriction sites (underlined) in the two primers were created by changing the normal nucleotide sequence (in capitals) of the GCM2 cDNA (GenBank accession no. NM_004752). The PCR conditions for preparing double-stranded GCM2 cDNA were: $50 \mu \mathrm{l}$ reaction volume; $5 \mu \mathrm{l}$ single-stranded cDNA template; $1 \mathrm{mM} \mathrm{MgSO}$; $0.3 \mu \mathrm{M}$ of each of the primers; $0.3 \mathrm{mM}$ dNTPs and 2.5 units of high-fidelity proof reading DNA polymerase enzyme (platinum pfx); initial denaturation at $94^{\circ} \mathrm{C}$ for $7 \mathrm{~min}$, followed by 40 cycles of denaturation at $94{ }^{\circ} \mathrm{C}$ for $1 \mathrm{~min}$, annealing at $65^{\circ} \mathrm{C}$ for $1 \mathrm{~min}$, extension at $68^{\circ} \mathrm{C}$ for $90 \mathrm{~s}$, and final extension at $68{ }^{\circ} \mathrm{C}$ for $15 \mathrm{~min}$. The $1593 \mathrm{bp} \mathrm{GCM} 2$ cDNA product was gel purified (Qiagen Inc.). The plasmid expression vector pPROEX HTc (Invitrogen Corp.) with sequence for $6 \times$ histidine $\left(\mathrm{His}_{6}\right)$ residues proximal to SalI restriction site was used to facilitate affinity purification of the recombinant protein. The expression vector pPROEX HTc and GCM2 cDNA insert were cut with the SalI and XhoI restriction enzymes and then ligated using 2.5 units of T4 DNA ligase (Fermentas) in 3:1 ratio $(\mathrm{V} / \mathrm{V})$ at $22^{\circ} \mathrm{C}$ for $6 \mathrm{~h}$. The ligated product was used to transform Escherichia coli ( $\mathrm{DH} 5 \alpha$ ) by heat shock method at $42{ }^{\circ} \mathrm{C}$ for $90 \mathrm{~s} \mathrm{(36)}$. The recombinants were screened by colony PCR using primers $5^{\prime}$-agcggataacaatttcacacagg- $3^{\prime}$ and $5^{\prime}$-caggctgaaaatcttctctcatc- $3^{\prime}$. Sequence of the GCM2 insert in positive clone was checked by DNA sequencing. 

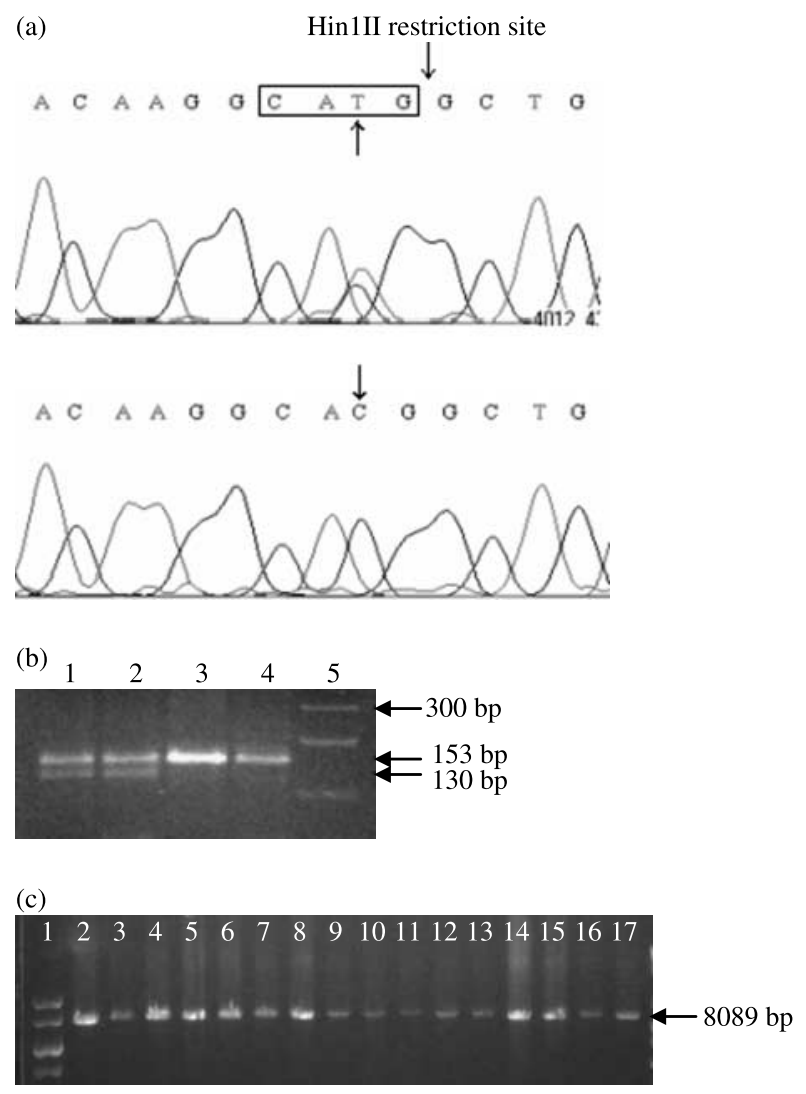

(d)

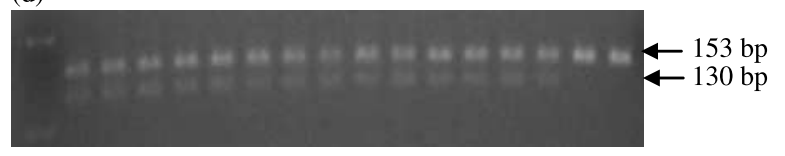

Figure 2 (a) Electropherogram of exon 2 region of GCM2 gene from a patient with $\mathrm{IH}$ showing the presence of $\mathrm{C}-\mathrm{T}$ transition (upper arrow, R110W mutation) leading to a new site for restriction (Hin1ll (box CATG $\downarrow$ )). Normal electropherogram of the same region is shown below (down arrow). (b) PCR-RFLP analysis of R110W mutation after overnight digestion of $153 \mathrm{bp}$ amplicon with 5 units of Hin1ll restriction enzyme using $2.5 \%$ agarose gel electrophoresis. Patients with C/T genotype showed the presence of three bands 153,130 , and 23 bp (last could not be visualized) (lanes 1 and 2). Subjects with the normal CC genotype (lanes 3 and 4) showed an intact band of $153 \mathrm{bp}$. A $100 \mathrm{bp}$ DNA ladder is in lane 5. (c) Absence of intragenic deletion of GCM2 alleles in patients and their relatives with R110W mutation. A single band of $8.09 \mathrm{~kb}$ amplified from GCM2 gene including exon 1-5 with intervening introns in subjects with R110W mutation (lanes 2-11, patients with $\mathrm{IH}$; lanes $12-15$, relatives of $\mathrm{IH}$ with $\mathrm{R} 110 \mathrm{~W}$, lanes 16 and 17, healthy controls). (d) Corresponding lanes of (c) showing heterozygous nature of the 8.09 product as revealed by the RFLP analysis of R110W mutation on the $153 \mathrm{bp}$ product amplified using the $8.09 \mathrm{~kb}$ product. RFLP analysis for R110W was performed as shown in (b).

Preparation of GCM2 clone containing R110W mutation and protein expression $\mathrm{A} C \mathrm{C}-\mathrm{T}$ transition at nucleotide 4711 position (GenBank accession no. NC_000006) was made, to create R110W mutation, using 5'-ctgcgacaaggcaTggctgaaacagc- $3^{\prime}$ and its complementary 5'-gctgtttcagccAtgccttgtcgcag- $3^{\prime}$ primers (nucleotides changed are in capitals) and the wild-GCM2-pPROEX HTc using quick change sitedirected mutagenesis kit (Stratagene, La Jolla, CA, USA). The presence of mutated cDNA was confirmed by sequencing. The plasmids with wild-type or mutated GCM2 cDNA inserts were then transformed into E. coli C43 (DE3) strains. Cells were then grown in two $500 \mathrm{ml}$ flasks, and protein expression was induced with isopropylthiogalactoside $(0.6 \mathrm{mM})$ and culture grown for $20 \mathrm{~h}$ at $30^{\circ} \mathrm{C}$. The recombinant proteins were purified by affinity chromatography under nondenaturing conditions from the soluble fraction of E. coli using the Ni-NTA agarose column (Qiagen Inc.), and identity of the protein was checked by western blot (Fig. 3) using anti-GCM2 antibody (Santa Cruz Biotechnology, Inc., Santa Cruz, CA, USA).

\section{Functional analysis of R110W mutation}

Electrophoretic mobility shift assay Electrophoretic mobility shift assay (EMSA) was performed to assess the DNA-binding ability of the wild-type GCM2 protein and its R110W mutant (Fig. 4) using biotin-labeled DNA probes (5'-gatcccgatgcgggtgcagatc- ${ }^{\prime}$ and complementary) containing GCM2 recognition element (underlined) (37). The $3^{\prime}$ end of the oligonucleotides were labeled with biotin using a commercial kit (Thermo Scientific, Rockford, IL, USA) and then annealed at $42{ }^{\circ} \mathrm{C}$ for $1 \mathrm{~h}$.

The EMSA reactions were carried out by incubating $1.4 \mathrm{ng}$ DNA probes with varying concentrations of wild-type $(2.5$ and $5 \mu \mathrm{g})$ or mutant $(2.5,5.0$, and $10 \mu \mathrm{g}) \mathrm{GCM} 2$ protein on ice for $30 \mathrm{~min}$ in a $20 \mu \mathrm{l}$ reaction mixture. The mixture contained $10 \mathrm{mM}$ HEPES (pH 8.0), 5\% glycerol, $50 \mathrm{mM} \mathrm{NaCl}, 5 \mathrm{mM} \mathrm{MgCl}_{2}, 2 \mathrm{mM}$ dithiothreitol, $0.1 \mathrm{mM}$ EDTA, $2 \mu \mathrm{g}$ BSA, and $1 \mu \mathrm{g}$ poly $(\mathrm{dI}-\mathrm{dC})$. The mixture was loaded on $4 \%$ native PAGE in $0.5 \times$ TBE buffer, transferred to a positively charged nylon membrane (Hybond $-\mathrm{N}+$, Amersham Biosciences) at $390 \mathrm{~mA}$ for $45 \mathrm{~min}$, and cross-linked using u.v. cross linker at $120 \mathrm{~mJ} / \mathrm{cm}^{2}$ for $1 \mathrm{~min}$ (Amersham Biosciences). DNA probe and its shift were detected using streptavidin-HRP conjugate and chemiluminescent luminol (Thermo Scientific) and $\mathrm{X}$-ray films. Specificity of the shift in the EMSA was

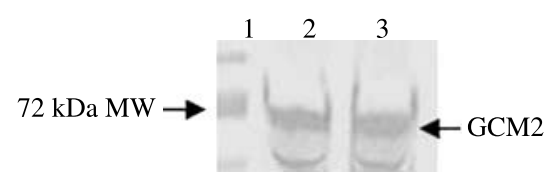

Figure 3 Immunoblot analysis showing $61 \mathrm{kDa}$ histidine-tagged wild-type (lane 2, $10 \mu \mathrm{g}$ protein) and R110W mutant GCM2 proteins (lane $3,10 \mu \mathrm{g}$ protein) expressed in E. coli. Staining was performed with anti-GCM2 antibody in 1:500 dilutions. Lane 1 contains molecular weight marker. 


\begin{tabular}{|lccccc|}
\hline GCM2 $(2.5 \mu \mathrm{g})$ & 0 & $+\mathrm{W}$ & $+\mathrm{W}$ & $+\mathrm{W}$ & $+\mathrm{W}$ \\
Anti-his tag ab $(1.0 \mu \mathrm{g})$ & 0 & 0 & + & 0 & 0 \\
Anti-VDR mab $(1.0 \mu \mathrm{g})$ & 0 & 0 & 0 & + & 0 \\
Cold DNA probe $(100 \mu \mathrm{M})$ & 0 & 0 & 0 & 0 & + \\
\hline
\end{tabular}

(a)

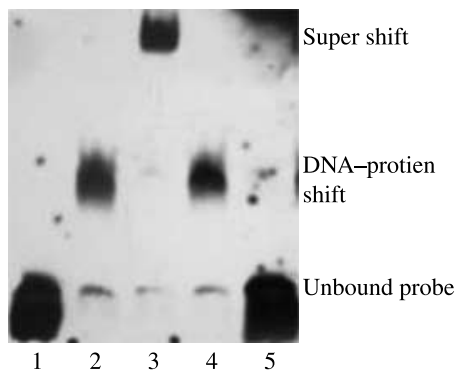

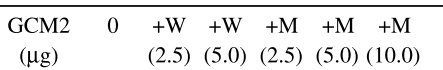

(b)

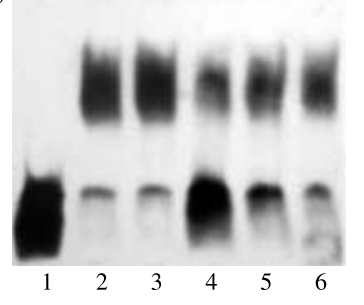

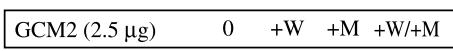

(c)

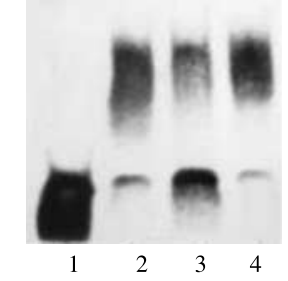

\begin{tabular}{llll|}
\hline $\mathrm{GCM} 2(5.0 \mu \mathrm{g})$ & 0 & $+\mathrm{W}$ & $+\mathrm{M}+\mathrm{W} /+\mathrm{M}+\mathrm{W}$
\end{tabular}

Cold DNA probe $(100 \mu \mathrm{M}) \quad 0 \quad 0000 \quad 0 \quad+$

(d)

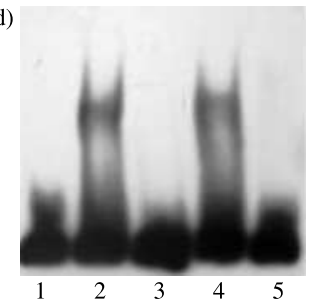

\begin{tabular}{|lcccc|}
\hline GCM2 $(2.5 \mu \mathrm{g})$ & 0 & $+\mathrm{W}$ & $+\mathrm{M}+\mathrm{W} /+\mathrm{M}+\mathrm{W}$ \\
Cold DNA probe $(100 \mu \mathrm{M})$ & 0 & 0 & 0 & 0 \\
+
\end{tabular}

(e)

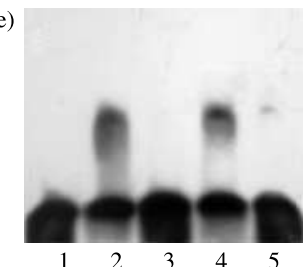

\begin{tabular}{|lllllllll|}
\hline GCM2 WT & $(2.5 \mu \mathrm{g})$ & 0 & + & 0 & 0 & 0 & + & + \\
GCM2 R110W $(2.5 \mu \mathrm{g})$ & 0 & 0 & + & 0 & + & + & 0 \\
GCM2 T370M & $(2.5 \mu \mathrm{g})$ & 0 & 0 & 0 & + & + & 0 & + \\
\hline
\end{tabular}

(f)

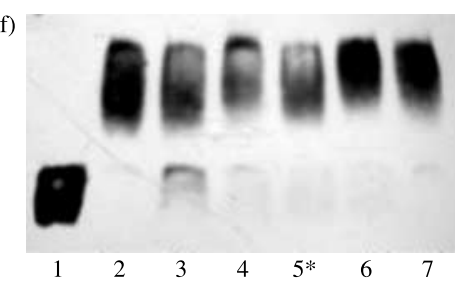

Figure 4 (a) EMSA showing the DNA binding of wild-type GCM2 protein (lane 2). DNA-protein super shift after the addition of $1.0 \mu \mathrm{g}$ mouse anti-histidine tag antibody (lane 3) but not with $1.0 \mu \mathrm{g}$ rat anti-VDR MAB (lane 4). Attenuation of DNA-protein complex with 100 -fold excess of unlabeled DNA probe (lane 5). Each lane from 2 to 5 contains $2.5 \mu \mathrm{g} \mathrm{GCM} 2$ protein. Lane 1 contains only DNA probe. (b) Effect of variability of protein concentration on DNA binding. Varying concentrations of wild-type GCM2 protein, i.e. $2.5 \mu \mathrm{g}$ (lane 2) and $5 \mu \mathrm{g}$ (lane 3 ) and R110W mutant GCM2 protein, i.e. $2.5 \mu \mathrm{g}$ (lane 4), $5 \mu \mathrm{g}$ (lane 5), and $10 \mu \mathrm{g}$ (lane 6) were used. (c) EMSA showing lack of dominant negative effect when R110W mutant GCM2 protein was added along with wild-type GCM2 protein to mimic heterozygous conditions (lane 4, each protein $2.5 \mu \mathrm{g}$ ). (d and e) The DNA binding of wild-type GCM2 protein with P1 (Fig. 4d) and P2 (Fig. 4e) DNA (CaSR gene) probes (lane 2 in both) and the absence of binding with mutant protein (lane 3 in both). Lack of any dominant negative effect of the R110W mutant protein on DNA-binding ability of the wild-type GCM2 protein (lane 4 in both). Attenuation of signal of DNA-protein complex with 100-fold excess of cold DNA (lane 5 in both). (f) EMSA showing reduced DNA binding of T370M (lane 4), which is similar to that of R110W mutant protein (lane 3). Lane 1 contains only DNA probe and lane 2 shows normal DNA-binding ability of the wild-type protein. *Lane 5 shows the reduced DNA binding when mixture of both $\mathrm{R} 110 \mathrm{~W}$ and T370M was added in equimolar concentration (1.25 $\mu \mathrm{g}$ each), thereby mimicking a compound heterozygous state observed in one of the patients with IH. Lanes 6 and 7 show the absence of dominant negative effect of either R110W or T370M mutations respectively on wild-type GCM2 protein.

checked by i) competition assay using a 100-fold excess of unlabeled DNA probe and ii) super shift of the DNA-GCM2 protein complex with anti-histidine tag antibody (positive control) and an unrelated antibody (negative control) i.e. VDR MAB (Catalog no. V2130X, US Biologicals, Swampscott, MA, USA). For the demonstration of super shift, DNA probe-GCM2 protein $(2.5 \mu \mathrm{g})$ was incubated with $1 \mu \mathrm{g}$ anti-histidine tag or anti-VDR antibody for $30 \mathrm{~min}$ at $4{ }^{\circ} \mathrm{C}$.
EMSA reaction was also carried out using biotin-labeled DNA probes containing GCM recognition sequence (underlined) present in the P1 (5'-tgtttcggcctgagggaggacttcac- $\left.3^{\prime}\right)$ and P2 (5'-aagacgcgccctcagcgacctg- $\left.3^{\prime}\right)$ promoters of the CaSR gene (27).

Transfections to assess the subcellular localization of R110W mutant pcDNA3.1(+) expression vector (Invitrogen Corp.) with full-length wild-type or mutant 
GCM2 cDNA inserts (pcDNA-GCM2) was constructed to assess nuclear translocation of the wild and mutant GCM2 protein in HeLa cells. The wild-type and mutant double-stranded GCM2 cDNA inserts were prepared as described above in the construction of GCM2 cDNA used for the EMSA except the forward primer (5'-ctattttcGgaTccctgggcggaaagc- $\left.3^{\prime}\right)$, which resulted in the amplification of cDNA containing 35 nucleotides proximal to translational initiation site to incorporate minimal Kozak sequence. The restriction site in the forward primer was BamH1 (underlined) and the changed nucleotides are in capital. Cells were transfected using TransFast reagent (Promega) as per the manufacturer's protocol.

Immunofluorescence HeLa cells maintained in DMEM with $10 \%$ FCS were seeded on cover slips in six-well plates $\left(10^{5}\right.$ cells/well) and grown to $70-80 \%$ of confluence and transfected with $2 \mu \mathrm{g}$ wild or mutant pcDNA-GCM2 vector per well. After $36 \mathrm{~h}$ of transfection, cells attached to the cover slips were rinsed with PBS ( $\mathrm{pH}$ 7.4), fixed with 4\% paraformaldehyde for $15 \mathrm{~min}$, and then washed three times ( $5 \mathrm{~min}$ each) with PBS containing $100 \mathrm{mmol}$ glycine. Cells were permeabilized with $0.1 \%$ Triton X-100 in PBS for $4 \mathrm{~min}$, washed three times (5 min each) with PBS ( $\mathrm{pH} 7.4$ ), blocked with $5 \% \mathrm{BSA}$ for $30 \mathrm{~min}$, and then incubated with anti-GCM2 antibody raised in goats $(1: 400$ dilution in 1\% BSA; Santa Cruz Biotechnology, Inc.) for $1 \mathrm{~h}$ at room temperature. This was followed by three washings of $5 \mathrm{~min}$ each with PBS and $30 \mathrm{~min}$ incubation with rabbit anti-goat IgG-FITC conjugate (1:150 dilution, Bangalore Genei P. Ltd., Bangalore, India). After three washings with PBS of 5 min each, cover slips were counterstained with $2 \mathrm{ml}$ Hoechst dye $(10 \mu \mathrm{g} / \mathrm{ml})$ for localization of the nucleus for $20 \mathrm{~min}$, rinsed with PBS, and then mounted on glass slides using 90\% glycerol in bicarbonate buffer and antifade para-phenylenediamine $(0.1 \%)$. Slides were scanned using a fluorescent microscope (ECLIPSE 80i, Nikon Instruments Inc., NY, USA), and the Hoechst and FITC signals were merged using a software NISElements version 2.2 (Nikon Instruments Inc., Melville, NY, USA; Fig. 6). The negative controls included i) HeLa cells transfected with pcDNA vector without GCM2 insert and stained as above and ii) untransfected HeLa stained only with rabbit anti-goat IgG-FITC conjugate with no prior GCM2 antibody staining.

\section{Structure of mutant GCM2 protein by construction of three-dimensional homology modeling}

To study the effect of R110W mutation, the structure of mutant protein was compared with that of wild-type protein. Homology modeling of the DNA-binding domain of wild-type and mutant human GCM2 proteins was based on the X-ray crystal structure of the murine DNA-binding domain of GCM1 protein complexed with octameric DNA (PDB id: 1ODH) (38). Murine and human species have a sequence identity of $69 \%$ in the region (residues 19-173). The three-dimensional model for the native and mutant R110W structures was constructed using the Modeller 8.2 module (39) of Discovery Studio 1.7 (http://accelrys.com). The position of the two zinc ions present in the template was retained in both the modeled structures. The complex structure was generated by assuming that the interface for GCM-DNA interaction was similar to that in mouse. Several models were built for wild and mutant GCM2 protein and subjected to energy minimization. The model with the most favorable energy constraint was selected in each case. Molecular dynamics simulation with the standard dynamics cascade protocol was also carried out for the mutant protein. The final structures were evaluated for their stereochemical quality using the program PROCHECK (40).

\section{Biochemical estimation}

The serum total calcium, phosphorus, alkaline phosphatase, urine calcium, and magnesium levels were measured using standard procedure in our laboratory (41). The intact iPTH was measured using a commercial kit using an IRMA (DiaSorin, Inc., Stillwater, MN, USA), minimum detection amount $0.7 \mathrm{ng} / \mathrm{l}$, normal range, $13-54 \mathrm{ng} / \mathrm{l}$ till 2006, and then afterwards by electrochemiluminescence immunoassay kits autoanalyzer (Elecsys-2010, Roche Diagnostics, normal range, $1.6-6.9 \mathrm{pmol} / \mathrm{l})$.

\section{Statistical analysis}

The difference in the frequency of various alleles in patients and controls was analyzed using Fisher's exact test and is shown in Table 2. The differences in the clinical and biochemical characteristics of the patients with and without R110W mutation were analyzed using Student's ' $t$ '-test, and data are shown as mean \pm s.D. in Table 3. The haplotype analysis using four SNPs, i.e. $-252 \mathrm{G} / \mathrm{T},-248 \mathrm{G} / \mathrm{C},-149$ $\mathrm{G} / \mathrm{A}$, and $-44 \mathrm{~T} / \mathrm{C}$ was performed using the SHEsis software program (http://analysis.bio-x.cn/ myAnalysis.php). The $P$ value $<0.05$ was considered significant.

\section{Results \\ DNA sequencing of the GCM2 gene in 24 patients with IH}

DNA sequencing of 24 patients with $\mathrm{IH}$ revealed the presence of five different types of single nucleotide substitutions in the GCM2 gene (Table 2). Four of 
Table 2 Summary of frequency of different substitutions observed in the GCM2 gene in patients with isolated hypoparathyroidism (IH) and healthy controls in the current study.

\begin{tabular}{|c|c|c|c|c|c|c|}
\hline $\begin{array}{l}\text { Serial } \\
\text { no. }\end{array}$ & Mutation/SNP found & $\begin{array}{l}\text { Region of the } \\
\text { GCM2 gene with } \\
\text { substitution }\end{array}$ & $\begin{array}{l}\text { Position of the } \\
\text { substitution }^{\mathrm{a}}\end{array}$ & IH (\%) & Controls (\%) & $P$ value \\
\hline 1 & $\mathrm{C}-\mathrm{T}$ heterozygous & Exon 2 & $1735646^{b}$ & $11 / 101(10.9 \%)$ & 0/655 (nil) & $<10^{-7}$ \\
\hline 2 & $-44 \mathrm{~T} / \mathrm{C}$ heterozygous & $5^{\prime}$ UTR & 1740328 & $2 / 101(1.9 \%)$ & $4 / 53(7.5 \%)$ & 0.18 \\
\hline 3 & $-149 \mathrm{G} / \mathrm{A}$ heterozygous & $5^{\prime}$ UTR & 1740433 & $5 / 101(5.0 \%)$ & $5 / 53(9.4 \%)$ & 0.31 \\
\hline 4 & $-248 \mathrm{G} / \mathrm{C}$ heterozygous & $5^{\prime}$ UTR & 1740532 & $22 / 101(21.8 \%)$ & $8 / 53(15.1 \%)$ & 0.40 \\
\hline 5 & $-248 \mathrm{G} / \mathrm{C}$ homozygous & $5^{\prime}$ UTR & 1740532 & $1 / 101(1.0 \%)$ & 0/53 (nil) & 0.99 \\
\hline 6 & $-252 \mathrm{G} / \mathrm{T}$ heterozygous & $\begin{array}{l}5^{\prime} \text { upstream of } \\
\text { translation } \\
\text { start site }\end{array}$ & 1740536 & $1 / 101(1.0 \%)$ & 0/53 (nil) & 0.99 \\
\hline
\end{tabular}

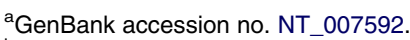

bame as position 4711 (GenBank accession no. NC_000006).

these five substitutions were in region $5^{\prime}$ upstream to the translation initiation site and one was in exon 2 .

Three of the four substitutions in the $5^{\prime}$ upstream region were in the $5^{\prime}$ UTR and included G-C transversion at $-248(n=4), \mathrm{G}-\mathrm{A}$ transition at -149 $(n=3)$, and T-C transition at $-44(n=1)$ position. In addition, there was a G-T transversion at -252 position $(n=1)$. One patient with $\mathrm{T}-\mathrm{C}$ transition at -44 also had a $\mathrm{G}-\mathrm{A}$ transition at -149 position.

The $\mathrm{C}-\mathrm{T}$ transition (Fig. 2a) observed in the exon 2 led to the change in CGG-TGG $(n=3)$ at codon 110 and therefore a change from arginine to tryptophan (R110W). The nucleotide sequence in the $3^{\prime}$ UTR was normal in all the 24 subjects.

Two of the five substitutions $\left(-248 \mathrm{G} / \mathrm{C}\right.$ in $5^{\prime} \mathrm{UTR}$ and R110W) could be confirmed by PCR-RFLP analysis. The $\mathrm{G}-\mathrm{C}$ transversion at -248 position lead to the creation of a sequence (TCGA $\rightarrow$ TCCA) and loss of restriction site for the enzyme TaqI $(\mathrm{T} \downarrow \mathrm{CGA})$. The transition of nucleotide $\mathrm{C}-\mathrm{T}$ in exon 2 (R11 $\overline{\mathrm{O}} \mathrm{W}$ ) created a sequence $\mathrm{CACG} \rightarrow \mathrm{CATG}$ and a restriction site for the enzyme Hin1II (CATG $\downarrow$; Fig. 2b). The other substitutions created no new restriction sites $(-44 \mathrm{~T} / \mathrm{C}$ and $-252 \mathrm{G} / \mathrm{T}$ ) or resulted in a restriction site for the rare enzyme CviKI-1(-149 G/A).

\section{Prevalence of R110W mutation and its relationship with clinical characteristics}

PCR-RFLP analysis showed the presence of heterozygous R110W change in $11 / 101$ (10.9\%) patients with IH. None of the 655 healthy controls showed the presence of R110W change. Clinical features including parameters related to hypoparathyroidism were not significantly different in patients with and without R110W mutation (Table 3). DNA sequencing of the coding exons of GCM2 gene was normal in all 11 patients except in 1 patient who had heterozygous $\mathrm{C}-\mathrm{T}$ change in exon 5, resulting in T370M variant. This change created a sequence $\mathrm{CACG} \rightarrow \mathrm{CATG}$ and a restriction site for the enzyme Hin1II (CATG $\downarrow$ ).

\section{Absence of intragenic deletion in subjects with R110W mutation and prevalence of T370M mutation}

Patients and relatives with R110W mutations showed a single band of expected $8.09 \mathrm{~kb}$ size (Fig. 2c) indicating the absence of large intragenic deletion in the GCM2 alleles. The contribution of both alleles in the PCR product was confirmed by RFLP analysis for the R110W

Table 3 Clinical and biochemical characteristics at presentation in patients with isolated hypoparathyroidism who did not show R110W mutation in comparison to 11 patients who showed mutation.

\begin{tabular}{lllr}
\hline & \multicolumn{2}{c}{ Patients with IH } \\
\cline { 2 - 4 } Parameters & Mutation absent $(n=90)$ & Mutation present $(n=11)$ & $\boldsymbol{P}$ value \\
\hline Male/female & $49 / 41$ & $6 / 5$ & 0.75 \\
BMI $\left(\mathrm{kg} / \mathrm{m}^{2}\right)$ & $20.2 \pm 4.3$ & $24.5 \pm 5.5$ & $<0.01$ \\
Age at presentation of symptoms (year) & $24.2 \pm 13.7$ & $32.0 \pm 16.6$ & 0.09 \\
Age at presentation to the hospital (year) & $31.4 \pm 13.9$ & $40.4 \pm 15.7$ & 0.05 \\
Serum total calcium (mmol/l) & $1.38 \pm 0.28$ & $1.28 \pm 0.2$ & 0.67 \\
Serum $\mathrm{PO}_{4}$ (mmol//) & $2.23 \pm 0.42$ & $2.06 \pm 0.29$ & 0.21 \\
Serum iPTH (pmol/l) & $0.69 \pm 0.82$ & $1.23 \pm 1.97$ & 0.41 \\
Frequency of basal ganglia calcification (\%) & $62 / 84(73.8 \%)$ & $8 / 11(72.7 \%)$ & 0.60 \\
Cataract (\%) & $46 / 84(54.80 \%)$ & $6 / 10(60.0 \%)$ & 0.49 \\
\hline
\end{tabular}

Data are shown as mean \pm s.D. Normal range for serum calcium $(\mathrm{Ca})=2.12-2.59 \mathrm{mmol} / \mathrm{l}$; inorganic phosphorus $\left(\mathrm{PO}{ }_{4}\right)=0.81-1.45 \mathrm{mmol} / \mathrm{l}$; intact parathyroid hormone $(\mathrm{iPTH})=1.6-6.8 \mathrm{pmol} / \mathrm{l}$; ionized calcium $(\mathrm{iCa})=1.10-1.38 \mathrm{mmol} / \mathrm{l}$. 
mutation using $8.09 \mathrm{~kb}$ product as template for PCR. As expected, all the patients with hypoparathyroidism and relatives were heterozygous for the R110W change indicating the presence of normal and mutant alleles in the $8.09 \mathrm{~kb}$ product.

The presence of T370M was confirmed by RFLP analysis in a patient who showed both R110W and T370M changes by amplifying a $502 \mathrm{bp}$ product incorporating $\mathrm{T} 370 \mathrm{M}$ variation. The product was amplified using primer pair no. 6 (Table 1). RFLP analysis was performed using 10\% PAGE after digestion of $502 \mathrm{bp}$ product with 5 units of Hin1II enzyme (Fig. 5a). None of the other 100 patients with $\mathrm{IH}$ and 117 healthy controls assessed for T370M variation showed this change. To differentiate compound heterozygous mutation versus the presence of two mutations in the single allele in the lone patient with IH who had both R110W and T370M changes, a simple allele discriminating PCR assay was performed as described by Bui \& Liu (42) to study the origin of mutations in the GCM2 alleles. Briefly, a $3.01 \mathrm{~kb}$ fragment of the GCM2 gene including nucleotides corresponding to R110W change in exon 2 and T370M change in exon 5 and all intervening introns was amplified using two allelesspecific forward primers and a common reverse primer (Table 1 , exon $5 \mathrm{~b}$ antisense). The $5^{\prime}$-ccatctgcgacaaggcTC- $3^{\prime}$ amplified wild-type allele and $5^{\prime}$-ccatctgcgacaaggcT - $^{\prime}$ amplified R110W allele. Subsequently, using internal primers (Table 1, pair no. 6), a second PCR was performed using wild and mutant $3.01 \mathrm{~kb}$ DNA product as template to amplify a 502 bp fragment, which included the nucleotides corresponding to the T370M change. The presence of T370M change in the wild-type and R110W alleles was checked by RFLP in the 502 bp products. The T370M change was observed in the 502 bp PCR product obtained from the wild allele but not from R110W mutant allele indicating compound heterozygous nature of the mutations (Fig. $5 b \& c$ ).

\section{Prevalence of various SNPs in $5^{\prime}$ upstream region in IH and healthy controls}

To determine the prevalence of various SNPs in the $5^{\prime}$ upstream region, DNA sequencing was performed instead of PCR-RFLP because two of the four SNPs, i.e. $-44 \mathrm{~T} / \mathrm{C}$ and $-252 \mathrm{G} / \mathrm{T}$ did not create any site for restriction enzyme. Moreover, all these substitutions were within a span of 250 nucleotides that could be sequenced by a single set of primer. The frequency of various SNPs in the $5^{\prime}$ upstream region was not significantly different between patients and the controls $(-248 \mathrm{G} / \mathrm{C}, 22(21.8 \%)$ versus $8(15.1 \%), \quad P=0.43 ;-149 \mathrm{G} / \mathrm{A}, 5(5.0 \%)$ versus $5(9.4 \%), \quad P=0.31 ;-44 \mathrm{~T} / \mathrm{C} 2(1.9 \%)$ versus 4 $(7.5 \%), P=0.2)$. The $-252 \mathrm{G} / \mathrm{T}$ change was not observed in any of the control subjects.

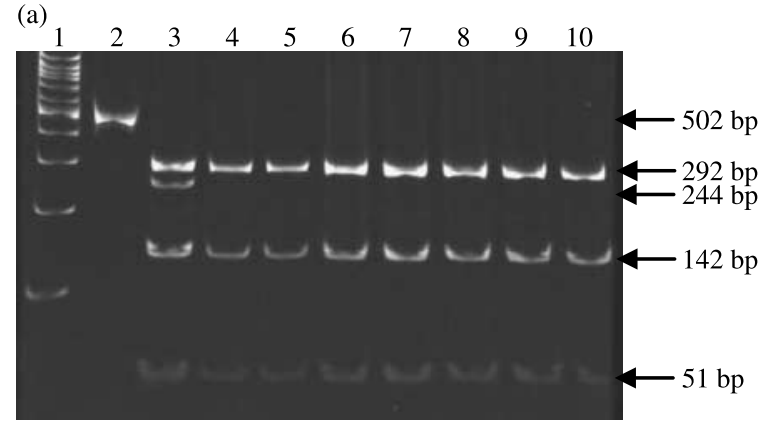

(b)
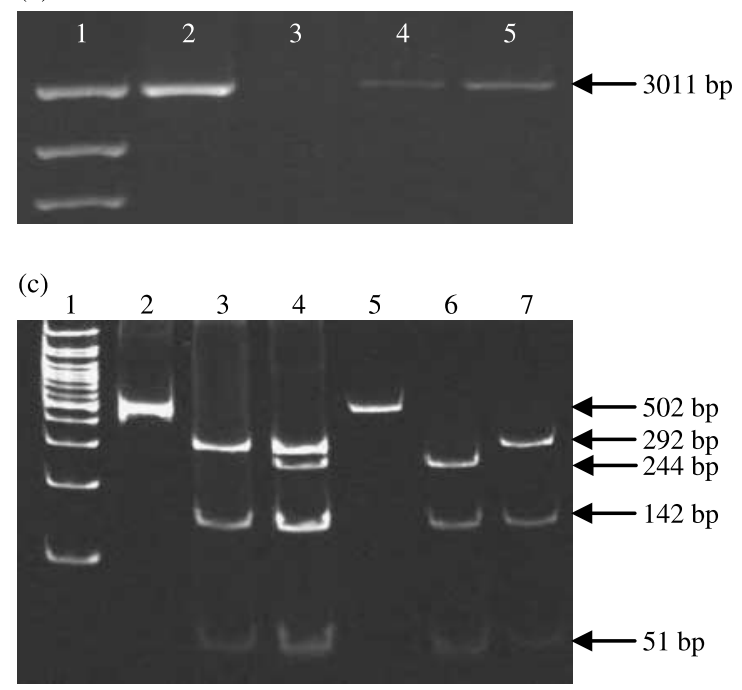

Figure 5 PCR-RFLP analysis of T370M mutation and demonstration of the compound heterozygous nature of R110W and T370M mutations in patients with IH who showed both the mutations. (a) Ten percent of native page showing RFLP analysis after overnight digestion of 502 bp PCR product with $5 \mathrm{U}$ of Hin1II enzyme. Lane 2 contains uncut 502 bp product. IH with $\mathrm{C} / \mathrm{T}$ genotype showed the presence of six bands of 292, 244, 142, 51, 48 and $17 \mathrm{bp}$ (lane 3, 48 and 17 bp could not be visualized). Subjects with wild CC genotype showed all the above bands except 244 and 48 bp (lanes 4-10). Lane 1 contains 100 bp DNA ladder. (b) Allele discriminating PCR to amplify wild-type and R110W alleles in IH. Lanes 2 and 4 contain the $3.01 \mathrm{~kb}$ product obtained using wild-type primer in a healthy control and patient with $\mathrm{IH}$ respectively. Lane 5 contains the amplification of $3.01 \mathrm{~kb}$ product using primer specific for R110Wmutated allele in $\mathrm{IH}$ with $\mathrm{R} 110 \mathrm{~W}$ mutation but its absence in a healthy control (lane 3). Lane 1 contains the 100 bp DNA ladder. (c) RFLP of $502 \mathrm{bp}$ PCR product obtained from genomic or allele-specific $3.01 \mathrm{~kb}$ DNA product. Lane 2, healthy control with 502 bp product from genomic DNA without Hin1ll enzyme; lane 3, healthy control without T370M mutation showing normal pattern of RFLP; lane 4, RFLP showing heterozygous nature of T370M mutation in patient with $\mathrm{IH}$ when 502 bp product was amplified from genomic DNA. Lane 6 shows same patient with the presence of T370M mutation in homozygous form when RFLP was performed using 502 bp product obtained from wild-type allele. Same patient showed the absence of T370M change when RFLP was performed using 502 bp product obtained from R110W mutant allele (lane 7). Lane 5 contains 502 bp product amplified from wild-type allele without Hin1ll enzyme (uncut control). Lane 1 contains 100 bp DNA ladder. 

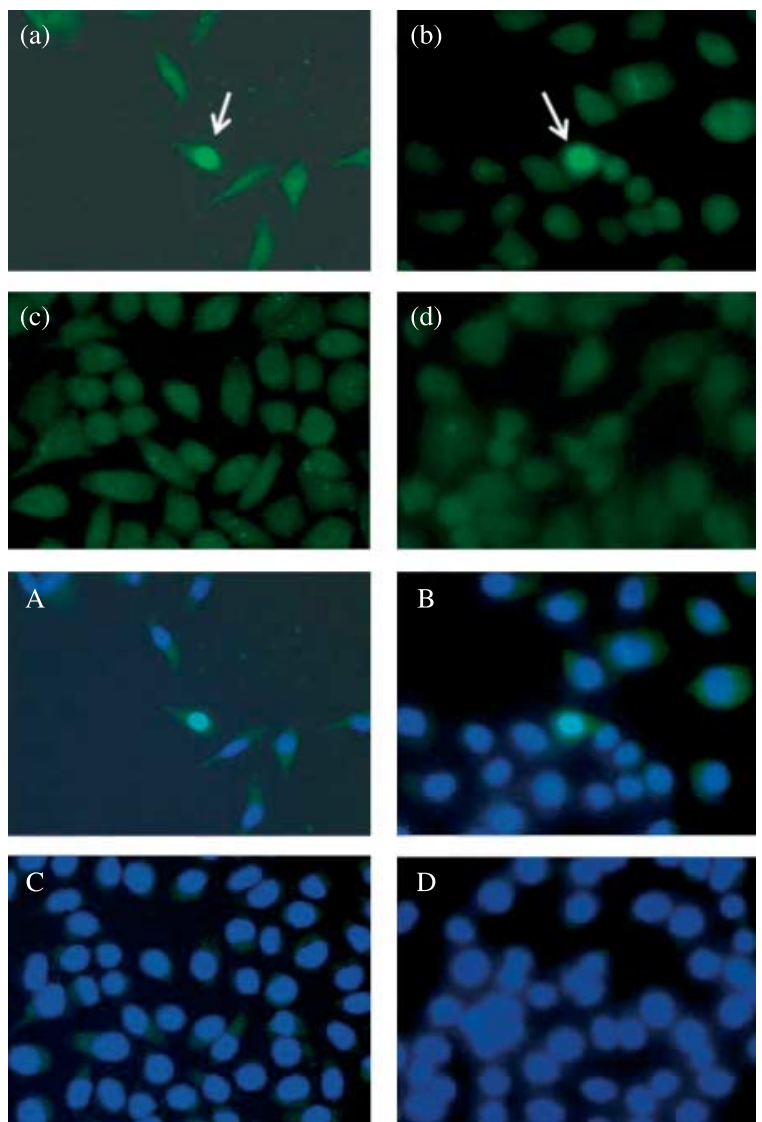

Figure 6 Immunofluorescence microscopy $(40 \times)$ following transfection of HeLa cells showing nuclear localization (arrow) of wild-type GCM2 protein (a) and R110W mutant protein (b), the absence of nuclear fluorescent signal in cells transfected with pcDNA3.1 vector without GCM2 insert (c) and untransfected cells (d). Upper panel (a-d) shows FITC-stained images and lower panel (A-D) shows merging of the FITC- and Hoechst-stained images.

\section{Haplotype analysis using four SNPs in the 5'UTR region of GCM2 gene}

Haplotypes were constructed using four SNPs, i.e. $-252 \mathrm{G} / \mathrm{T},-248 \mathrm{G} / \mathrm{C},-149 \mathrm{G} / \mathrm{A}$, and $-44 \mathrm{~T} / \mathrm{C}$ of the GCM2 gene. GGGT was the most common haplotype observed in patients with IH and controls. Its frequency was not significantly different among patients with and without R110W mutation and healthy controls (90.0, 84.4 , and $87.7 \%$ respectively, $P=$ NS). Similarly, there was no significant difference in the frequency of other haplotypes observed in these groups.

\section{Presence of R110W mutation and SNPs in the $5^{\prime}$ UTR in first-degree relatives}

Four of the 13 family members (Fig. 1) had heterozygous R110W mutation. On DNA sequencing of all the coding exons in these four relatives, there was no other sequence variation observed. However, all these family members were clinically asymptomatic and had normal serum total calcium, inorganic phosphorus, and serum iPTH. The $-248 \mathrm{G} / \mathrm{C}$ transversion in $5^{\prime}$ UTR was also observed in 2 of the 13 relatives.

\section{DNA sequencing of promoters of CaSR gene}

Sequencing of the $\mathrm{P} 1$ and $\mathrm{P} 2$ promoter regions including GCM recognition elements was normal in patients with $(n=11)$ and without $(n=10)$ R110W mutation, their 13 relatives, and 10 healthy controls.

\section{Electrophoretic mobility shift assay}

With synthetic oligonucleotides containing octameric GCM response elements Wild-type GCM2 protein led to complete DNA probe shift (Fig. 4, lane 2). The protein-DNA complex showed super shift with antihistidine antibody but not with VDR antibody (Fig. 4a, lanes 3 and 4 respectively). When the wild and mutant GCM2 proteins were added in different concentrations in EMSA reaction, the latter bound with much lower efficacy (Fig. 4b). EMSA reaction carried out to evaluate the dominant negative effect of heterozygous R110W mutation with a mixture of $2.5 \mu$ g wild-type GCM2 protein and $2.5 \mu \mathrm{g}$ mutant GCM2 protein revealed no attenuation of DNA-protein signal (Fig. 4c, lane 4). In contrast, there was complete attenuation of DNA-protein complex when EMSA was carried out with 100-fold excess of unlabeled DNA probe (Fig. 4a, lane 5).
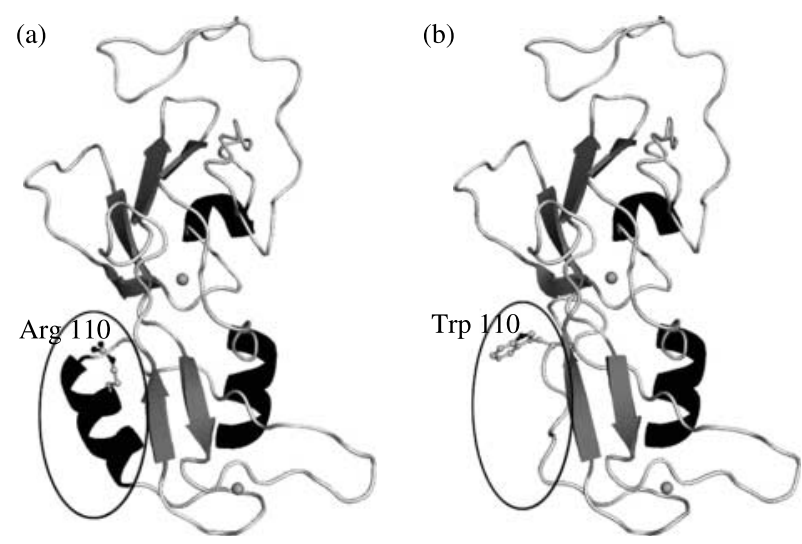

Figure 7 Structural model of (a) wild-type and (b) R110W mutant GCM2 proteins indicating the arginine and tryptophan residues (ball-and-stick) in the native and mutant protein respectively. The resultant conformational change (encircled) from helix (black; amino acid residues 107-115) to the random coil (light grey) structure in the protein backbone at the site of mutation can be observed. The $\beta$-sheet is represented in dark grey. The zinc ions are indicated as grey spheres. The figure was made using PYMOL software (www.pymol.org). 

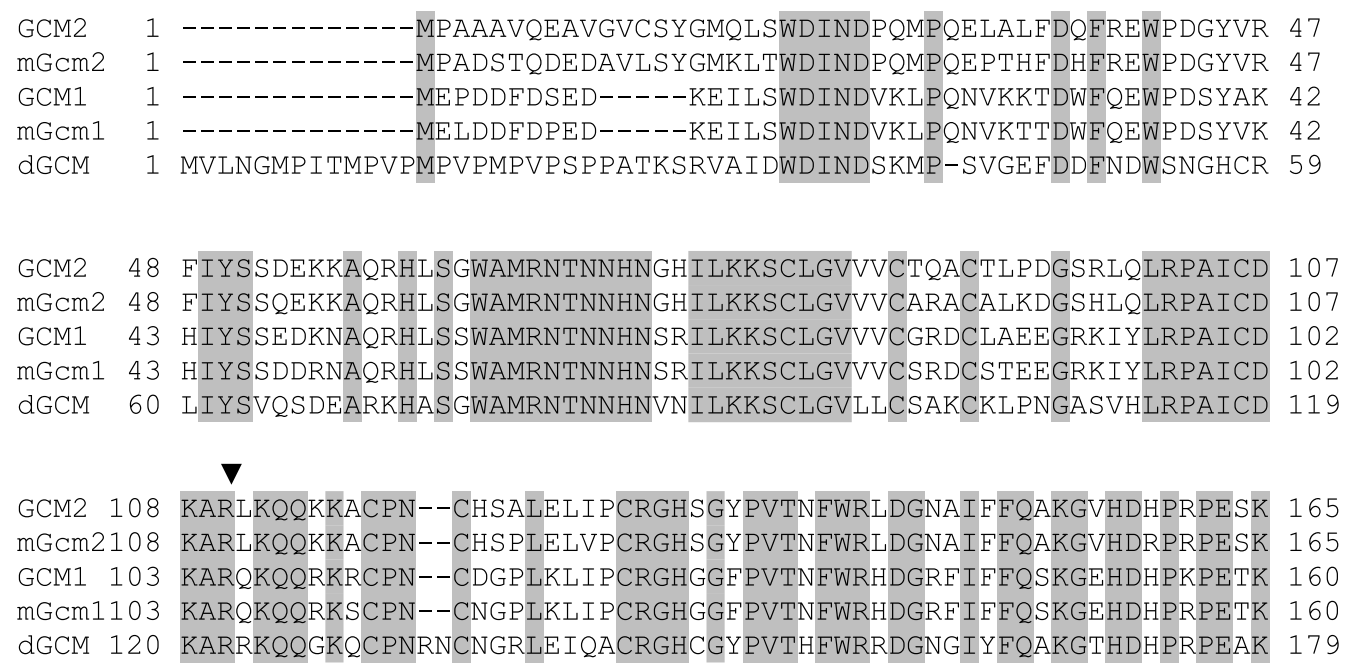

GCM2 166 SETEARRS 173

mGcm2 166 SETEGRRS 173

GCM1 161 LEAEARRA 168

mGCm1 161 LEAEARRA 168

dGCM 180 GSTEARRL 187

Figure 8 Shaded area represents the conserved amino acid sequence of the GCM protein in different species (human, GCM2 and GCM1; mouse, $\mathrm{mGcm} 2$ and $\mathrm{mGcm} 1$; Drosophila, dGCM). The amino acid arginine shown with $\boldsymbol{\nabla}$ is part of conserved residues and was substituted with tryptophan (W) in R110W mutation. Sequences were aligned by clustalW2 program (http://www.ebi.ac.uk/Tools/clustalw2/index.html).

With oligonucleotides containing GCM response elements in the P1 and P2 promoter regions of CaSR The wild-type GCM2 protein resulted in significant shift of DNA probe designed from the P1 and P2 promoter regions of the CaSR gene. In contrast, mutant GCM2 protein did not shift $\mathrm{P} 1$ or $\mathrm{P} 2$ probes (Fig. $4 \mathrm{~d}$ and e).

EMSA with T370M protein The EMSA experiments were also carried out using T370M-recombinant protein, which was prepared using site-directed mutagenesis as described above for R110W protein. The protein-DNA binding obtained with $\mathrm{T} 370 \mathrm{M}$ mutant protein was comparable to that obtained with R110W mutant protein (Fig. 4a, lanes 3 and 4). When a mixture of both R110W and $\mathrm{T} 370 \mathrm{M}$ was added in equimolar concentration (1.25 $\mu \mathrm{g}$ each) to mimic the compound heterozygous state observed in the patient, there was a significant reduction in the DNA-protein complex (Fig. 4f, lane 5) when compared to that observed with wild-type protein. There was no dominant negative effect of T370M mutations on wild-type GCM2 protein (Fig. 4f, lane 7).

\section{Immunofluorescence}

Both the wild-type GCM2 protein and its R110W mutant showed localization to the nucleus and there was no difference in the intensity of FITC fluorescence signal. Both the negative controls showed no GCM2 protein signal in the HeLa cell nuclei (Fig. 6).

\section{Effect of R110W mutation on structure of GCM2 protein}

The presence of R110W mutation led to a structural change in the backbone conformation of amino acid residues 107-115 from a helical to a random coil structure (Fig. 7). This change would result in impairment in the DNA-binding ability of the GCM2 protein. In addition, no hydrogen bond was observed between W110 and backbone carbonyl oxygen A104 (Fig. 7).

\section{Discussion}

The pathogenesis of IH has been a subject of interest since 1966, when Blizzard et al. first identified parathyroid autoantibodies in 33\% of their patients using indirect immunofluorescence. Organ-specific CaSR autoantibodies have been reported in patients with IH (10-12). Söderbergh et al. could not find any evidence of CaSR autoantibodies in hypoparathyroidism associated with type 1 APS (43). On the other hand, there are reports of CaSR gene mutations in a subset of patients with $\mathrm{IH}(15,16)$. Thus, IH is a heterogeneous group of disorders with variable etiopathogenesis; in the absence of complete understanding of pathogenetic mechanisms, many patients are classified as idiopathic.

The present study was conducted in view of the recent reports of mutations in the GCM2 gene in patients with familial hypoparathyroidism (22-27). The gene knockout mice have revealed a key role of the GCM protein in 
fetal parathyroid development (30). The GCM2 gene is also expressed in adult human parathyroid gland (32) and has response elements in the $\mathrm{P} 1$ and $\mathrm{P} 2$ promoters of the CaSR gene (27). Silencing of the GCM2 gene by shRNA in human parathyroid cells led to a decreased expression of the CaSR, but had no significant effect on the PTH, VDR, 25-hydroxyvitamin D (3)-1 $\alpha$-hydroxylase, and proliferating cell nuclear antigen expression (44). Interestingly, the result of EMSA experiments carried out in the current study revealed that the presence of R110W GCM2 mutation led to a binding abnormality with the P1-P2 GCM response elements of the CaSR. A down-regulation of CaSR by mutant GCM2 and decreased expression of CaSR would result in increased PTH secretion, unlike observed in patients with IH. The above fact coupled with the observation that relatives of patients with the same R110W heterozygous mutation were asymptomatic indicates that the binding defects on CaSR response elements due to the mutation of GCM2 alone would not explain the pathophysiology of hypoparathyroidism. Alternatively, this may suggest that GCM2 may interact with genes other than the CaSR.

To date, there are six reports assessing mutations in the GCM2 gene in patients with familial hypoparathyroidism. In five of these reports, mutations were observed in 14 patients. The homozygous mutations observed included a deletion of exons 1-4 (22), missense R47L (23), and G63S (24). All heterozygous family members were unaffected in these studies (22-24). The heterozygous mutations observed included c.1389delT $(26,27)$ or c.1399delC mutation (26). Two of the above studies also included $20 \mathrm{IH}$ patients and reported normal GCM2 gene sequence in all of them $(22,25)$.

In the current study, the presence of R110W change did not affect the nuclear translocation of the mutant protein. However, normal nuclear translocation would not exclude impaired DNA binding and transactivation. In fact, GCM2 protein with R47L and G63S mutations has been reported to demonstrate normal nuclear localization but impaired transcriptional activity $(23,24)$. Though transactivation experiments could not be performed in the current study, results of the EMSA experiments indicated that under homozygous conditions, the presence of R110W mutation led to a significant reduction in DNA binding with GCM response element. Reduction in DNA-binding capacity was not observed in R110W heterozygous condition. However, the presence of coexistent compound mutation even in heterozygous state such as R110W and T370M observed in one of our patients could result in significant loss of DNA-binding function of the GCM2 protein.

The present study revealed a heterozygous $\mathrm{C}-\mathrm{T}$ transition in the exon 2 leading to a change of 110th codon from CGG $\rightarrow$ TGG in $10.9 \%$ of the patients with IH. The disparity between the results of the previous studies showing the absence of mutation in 20 patients with IH and the current study showing 10.9\% prevalence of R110W in 101 patients could be because of the differences in the race or sample size. Occurrence of this R110W change in $10.9 \%$ patients with $\mathrm{IH}$ and its absence in 655 unrelated healthy controls from same ethnic North Indian background indicate that the nucleotide change is not a simple SNP. Though patients with IH recruited in the current study were from unrelated families, in the absence of complete information of family tree, we cannot exclude the possibility of common ancestor. The haplotype analysis performed using four polymorphic variables in the $5^{\prime}$ UTR region of the GCM2 revealed no significant difference in patients with and without R110W and controls; however, further haplotype analysis using microsatellite markers flanking the GCM2 gene would help to identify the possibility of founder effect as the cause of high prevalence of R110W mutation in our cohort of patients with IH.

The R110W missense mutation in the DNA-binding domain is likely to be relevant because arginine at codon 110 in GCM2 protein is part of a conserved peptide sequence in different species (Fig. 8) (45). Theoretically, it can be hypothesized that replacement of positively charged polar amino acid arginine with nonpolar amino acid tryptophan might affect the DNA-binding ability of the R110W GCM2 protein. A mutation resulting in similar amino acid change (R47W) in the PAX9 gene led to reduced binding of PAX9 transcription factor with the DNA response element (46). In fact, EMSA experiment in the current study showed a significant reduction in the DNA-binding ability of the mutant GCM2 protein. Moreover, the molecular modeling of the GCM2 protein revealed change in the structure from helical to a random coil with R110W mutation at amino acid residues 107-115. This mutation also results in the loss of the hydrogen bond, which was present in the wild-type protein due to the polar side chain of R110 and backbone carbonyl oxygen of A104. The conformational change as well as the disruption of hydrogen bond would result in impairment in the DNA-binding ability of the GCM2 protein (Fig. 4). A similar molecular mechanism involving the loss of polar interactions due to a single-point mutation at residue R110 has been predicted earlier (47). Based on molecular interactions of the wild-type and mutant structural models, 21 amino acid residues were predicted as candidates where a point mutation would affect the activity of GCM2 and cause hypoparathyroidism (47). A detailed analysis of the polar side chain interaction to other protein residues, DNA, or the bound zinc ions revealed that the nature of interactions between the present model structure and that reported in the earlier study (47) was similar.

The expressivity of R110W mutation in terms of clinical illness varied because 4 of the 13 nonaffected first-degree family members studied also had R110W substitution. All these relatives were asymptomatic and 
had normal serum PTH values. The variable expression of the clinical syndrome in subjects with same heterozygous mutation can occur with i) parental genetic imprinting; ii) dominant negative effect of mutation; and iii) compound, digenic, or polygenic mutations. The genetic imprinting is unlikely to be the cause because experimental evidences do not favor paternal or maternal imprinting in GCM2 alleles (29). Moreover, a theoretical possibility of imprinting in GCM2 gene in human could also be ruled out because of the lack of family history in our study, which is usually present in genetically imprinted disorders (48). Similarly, family history is a characteristic feature of dominant negative heterozygous mutations $(26,27)$. Moreover, the results of the EMSA experiments in the current study did not support dominant negative effect of R110W mutant protein.

Individuals with heterozygous R110W genotype might also express clinical hypoparathyroidism if they have multiple mutations in the same (compound) or other genes with synergistic effect (digenic) (49, 50). Thus, if individuals with heterozygous R110W mutation in the DNA-binding region of GCM2 gene have additional mutations in its DNA-binding elements, the effect of digenic mutation might result in complete loss of transcription ability of the GCM2 protein. In the current study, only 1 of the 11 patients with $\mathrm{IH}$ and R110W had compound mutation in the GCM2 gene (T370M), and none had mutation in the natural response elements of the GCM2 (i.e. CaSR gene). Interestingly, the patient showing compound heterozygous mutation was a 48-year-old male who also had HLA-B27-positive ankylosing spondylitis and was reported earlier (51). Results of the EMSA experiments in the current study indicate possibility of significant loss of GCM2 protein function in this patient.

The variable expression of a heterozygous mutation has been reported in several other disorders such as hyperthyroidism due to the activating mutation of TSH receptor (52), myotonia congenita (53), retinitis pigmentosa (54), classical (55), and nonclassical congenital adrenal hyperplasia (56). The variability in phenotypic expression of heterozygous mutation may be conditioned by polygenic mechanism or by environmental factors $(57,58)$. Among the polygenic factors, possibilities include mutations in the parathyroid glandrelated transcription factor proteins other than GCM2 such as PAX1, PAX9, GATA3, Hoxa3, TBX1, and SOX3 $(6,9,59-62)$.

While the present study demonstrates R110W change in $10.9 \%$ of patients with $\mathrm{IH}$ and none of the controls, the study has limitations. Complete sequencing of the open-reading frame of the GCM2 gene was carried out in only 32 patients because of the cost factors. Sequencing of the GCM2 gene in all the 101 patients might have revealed additional changes in the coding regions.
To conclude, the results of the present study indicate that $10.9 \%$ of the patients with $\mathrm{IH}$ had a heterozygous R110W mutation in the DNA-binding region of GCM2 protein. The mutation was seen only among patients with hypoparathyroidism and their family members and not in any of the 655 healthy controls. The R110W mutant represented the loss of function in homozygous form or in compound heterozygous state with T370M change in EMSA experiments. Further studies using genome-wide scan may identify digenic/polygenic mutations or the presence of unique environmental factors as the cause of variable expression of disease in those with R110W mutation.

\section{Declaration of interest}

The authors declare that there is no conflict of interest that could be perceived as prejudicing the impartiality of the research reported.

\section{Funding}

Neeraj Tomar and Punit Kaur thank Indian Council of Medical Research for the grant of Senior Research Fellowship and financial support for Bio-Medical Informatics Centre respectively.

\section{Author contribution statement}

All authors have contributed in the study and accepted responsibility for the content of the manuscript. Neeraj Tomar performed the major work of the manuscript including experiments related to EMSA, contributed in writing of the manuscript, and analyzed the sequence of the GCM2 gene. Hema Bora performed sequencing of the GCM2 gene. Transfection experiments were jointly conducted by Ratnakar Singh and Dr Shyam Singh Chauhan. Nandita Gupta performed iPTH, and $25(\mathrm{OH}) \mathrm{D}$ assays for the study subjects. Punit Kaur performed the molecular modeling of the mutant GCM2 protein and contributed in the writing of the manuscript. Dr Yagya Dutta Sharma contributed in the analysis of the GCM2 gene and editing of the manuscript. Ravinder Goswami planned the study and contributed in the supervision, analyzing the results of functional and immunofluorescence studies, and writing of the manuscript.

\section{Acknowledgements}

The authors acknowledge the help of Dr S Saxena (Staff Scientist, National Institute of Immunology, New Delhi) for providing HeLa cells.

\section{References}

1 Betterle C, Dal Pra C, Mantero F \& Zanchetta R. Autoimmune adrenal insufficiency and autoimmune polyendocrine syndromes: autoantibodies, autoantigens, and their applicability in diagnosis and disease prediction. Endocrine Reviews 200223 327-364.

2 Bringhurst FR, Demay MB \& Kronenberg HM. Hormones and disorders of mineral metabolism. In Williams Textbook of Endocrinology, edn 11, ch 27, pp 1203-1268. Eds HM Kronenberg, S Melmed, KS Polonsky \& PR Larsen. Philadelphia: Sunders Elsevier, 2008.

3 Pollak MR, Brown EM, Estep HL, McLaine PN, Kifor O, Park J, Hebert SC, Seidman CE \& Seidman JG. Autosomal dominant hypocalcaemia caused by a $\mathrm{Ca}(2+)$-sensing receptor gene mutation. Nature Genetics 19948 303-307. 
4 Parkinson DB \& Thakker RV. A donor splice site mutation in the parathyroid hormone gene is associated with autosomal recessive hypoparathyroidism. Nature Genetics 19921 149-152.

5 Sunthornthepvarakul T, Churesigaew S \& Ngowngarmratana S. A novel mutation of the signal peptide of the preproparathyroid hormone gene associated with autosomal recessive familial isolated hypoparathyroidism. Journal of Clinical Endocrinology and Metabolism 199984 3792-3796.

6 Bowl MR, Nesbit MA, Harding B, Levy E, Jefferson A, Volpi E, Rizzoti K, Lovell-Badge R, Schlessinger D, Whyte MP \& Thakker RV. An interstitial deletion-insertion involving chromosomes 2p25.3 and Xq27.1, near SOX3, causes X-linked recessive hypoparathyroidism. Journal of Clinical Investigation $20051152822-2831$.

7 de la Chapelle A, Herva R, Koivisto M \& Aula P. A deletion in chromosome 22 can cause DiGeorge syndrome. Human Genetics 198157 253-256.

8 Björses P, Halonen M, Palvimo JJ, Kolmer M, Aaltonen J, Ellonen P, Perheentupa J, Ulmanen I \& Peltonen L. Mutations in the AIRE gene: effects on subcellular location and transactivation function of the autoimmune polyendocrinopathy-candidiasis-ectodermal dystrophy protein. American Journal of Human Genetics $2000 \mathbf{6 6}$ 378-392.

9 Van Esch H, Groenen P, Nesbit MA, Schuffenhauer S, Lichtner P, Vanderlinden G, Harding B, Beetz R, Bilous RW, Holdaway I, Shaw NJ, Fryns JP, Van de Ven W, Thakker RV \& Devriendt K. GATA3 haplo-insufficiency causes human HDR syndrome. Nature $2000 \mathbf{4 0 6} 419-422$.

10 Li Y, Song YH, Rais N, Connor E, Schatz D, Muir A \& Maclaren N. Autoantibodies to the extracellular domain of the calcium sensing receptor in patients with acquired hypoparathyroidism. Journal of Clinical Investigation 19964 910-914.

11 Goswami R, Brown EM, Kochupillai N, Gupta N, Rani R, Kifor O \& Chattopadhyay N. Prevalence of calcium sensing receptor autoantibodies in patients with sporadic idiopathic hypoparathyroidism. European Journal of Endocrinology 2004 150 9-18.

12 Mayer A, Ploix C, Orgiazzi J, Desbos A, Moreira A, Vidal H, Monier JC, Bienvenu J \& Fabien N. Calcium-sensing receptor autoantibodies are relevant markers of acquired hypoparathyroidism. Journal of Clinical Endocrinology and Metabolism $2004 \mathbf{8 9}$ 4484-4488.

13 Shoback D. Clinical practice. Hypoparathyroidism. New England Journal of Medicine 2008359 391-403.

14 Goswami R, Marwaha RK, Goswami D, Gupta N, Ray D, Tomar N \& Singh S. Prevalence of thyroid autoimmunity in sporadic idiopathic hypoparathyroidism in comparison to type 1 diabetes and premature ovarian failure. Journal of Clinical Endocrinology and Metabolism $2006914256-4259$.

15 De Luca F, Ray K, Mancilla EE, Fan GF, Winer KK, Gore P, Spiegel AM \& Baron J. Sporadic hypoparathyroidism caused by de Novo gain-of-function mutations of the Ca $(2+)$-sensing receptor. Journal of Clinical Endocrinology and Metabolism 1997 82 2710-2715.

16 Shiohara M, Mori T, Mei B, Brown EM, Watanabe T \& Yasuda T. A novel gain-of-function mutation (F821L) in the transmembrane domain of calcium-sensing receptor is a cause of severe sporadic hypoparathyroidism. European Journal of Pediatrics 2004163 94-98.

17 Suprasdngsin C, Wattanachal A \& Preeysombat C. Parathyroid hormone gene mutation in patient with hypoparathyroidism. Mahidol University, Bangkok, vol 128, Annual Research Abstract 164, 2001.

18 Goswami R, Mohapatra T, Gupta N, Rani R, Tomar N, Dikshit A \& Sharma RK. Parathyroid hormone gene polymorphism and sporadic idiopathic hypoparathyroidism. Journal of Clinical Endocrinology and Metabolism $2004894840-4845$.

19 Sarin R, Tomar N, Ray D, Gupta N, Sharma YD \& Goswami R. Absence of pathogenic calcium sensing receptor mutations in sporadic idiopathic hypoparathyroidism. Clinical Endocrinology $200665359-363$.

20 Goswami R, Gupta N, Ray D, Rani R, Tomar N, Sarin R \& Vupputuri MR. Polymorphisms at +49 A/G and CT60 sites in the $3^{\prime}$ UTR of the CTLA-4 gene and APECED-related AIRE gene mutations analysis in sporadic idiopathic hypoparathyroidism. International Journal of Immunogenetics 200532 393-400.

21 Ray D, Tomar N, Gupta N \& Goswami R. Protein tyrosine phosphatase non-receptor type 22 (PTPN22) gene R620W variant and sporadic idiopathic hypoparathyroidism in Asian Indians. International Journal of Immunogenetics 200633 237-240.

22 Ding C, Buckingham B \& Levine MA. Familial isolated hypoparathyroidism caused by a mutation in the gene for the transcription factor GCMB. Journal of Clinical Investigation 2001108 1215-1220.

23 Baumber L, Tufarelli C, Patel S, King P, Johnson CA, Maher ER \& Trembath RC. Identification of a novel mutation disrupting the DNA binding activity of GCM2 in autosomal recessive familial isolated hypoparathyroidism. Journal of Medical Genetics $2005 \mathbf{4 2}$ 443-448.

24 Thomée C, Schubert SW, Parma J, Lê PQ, Hashemolhosseini S, Wegner M \& Abramowicz MJ. GCMB mutation in familial isolated hypoparathyroidism with residual secretion of parathyroid hormone. Journal of Clinical Endocrinology and Metabolism 2005 90 2487-2492.

25 Maret A, Ding C, Kornfield SL \& Levine MA. Analysis of the GCM2 gene in isolated hypoparathyroidism: a molecular and biochemical study. Journal of Clinical Endocrinology and Metabolism 200893 $1426-1432$.

26 Mannstadt M, Bertrand G, Muresan M, Weryha G, Leheup B, Pulusani SR, Grandchamp B, Jüppner H \& Silve C. Dominantnegative GCMB mutations cause an autosomal dominant form of hypoparathyroidism. Journal of Clinical Endocrinology and Metabolism 200893 3568-3576.

27 Canaff L, Zhou X, Mosesova I, Cole DE \& Hendy GN. Glial cells missing-2 (GCM2) transactivates the calcium-sensing receptor gene: effect of a dominant-negative GCM2 mutant associated with autosomal dominant hypoparathyroidism. Human Mutation 2009 30 85-92.

28 Hosoya T, Takizawa K, Nitta K \& Hotta Y. Glial cells missing: a binary switch between neuronal and glial determination in Drosophila. Cell 199582 1025-1036.

29 Schreiber J, Riethmacher-Sonnenberg E, Riethmacher D, Tuerk EE, Enderich J, Bösl MR \& Wegner M. Placental failure in mice lacking the mammalian homolog of glial cells missing, GCMa. Molecular and Cellular Biology $2000202466-2474$.

30 Günther T, Chen ZF, Kim J, Priemel M, Rueger JM, Amling M, Moseley JM, Martin TJ, Anderson DJ \& Karsenty G. Genetic ablation of parathyroid glands reveals another source of parathyroid hormone. Nature 2000406 199-203.

31 Kim J, Jones BW, Zock C, Chen Z, Wang H, Goodman CS \& Anderson DJ. Isolation and characterization of mammalian homologs of the Drosophila gene glial cells missing. PNAS 1998 95 12364-12369.

32 Kebebew E, Peng M, Wong MG, Ginzinger D, Duh QY \& Clark OH. GCMB gene, a master regulator of parathyroid gland development, expression, and regulation in hyperparathyroidism. Surgery 2004 136 1261-1266.

33 Goswami R, Srikanta SS \& Kochupillai N. Prevalence and significance of pancreatic islet cell and adrenal antibodies in patients with Graves' disease. Indian Journal of Medical Research $1995101201-206$.

34 Goswami R, Goel S, Tomar N, Gupta N, Lumb V \& Sharma YD. Prevalence of clinical remission in patients with sporadic idiopathic hypoparathyroidism. Clinical Endocrinology 2009 (10.1111/j.1365-2265.2009.03653).

35 Goswami R, Marwaha RK, Gupta N, Tandon N, Sreenivas V, Tomar N, Ray D, Kanwar R \& Agarwal R. Prevalence of vitamin D deficiency and its relationship with thyroid autoimmunity in Asian Indians: a community-based survey. British Journal of Nutrition $2009101-5$.

36 Plasmids and their usefulness in molecular cloning. In Molecular Cloning - A Laboratory Manual, edn 3, ch 1, pp 1.116-1.118. Eds J Sambrook \& DW Russell. Cold Spring Harbor, NY: Cold Spring Harbor Laboratory. 
37 Schreiber J, Enderich J \& Wegner M. Structural requirements for DNA binding of GCM proteins. Nucleic Acids Research 199826 2337-2343.

38 Cohen SX, Moulin M, Hashemolhosseini S, Kilian K, Wegner M \& Müller CW. Structure of the GCM domain-DNA complex: a DNAbinding domain with a novel fold and mode of target site recognition. EMBO Journal 200322 1835-1845.

39 Sali A, Potterton L, Yuan F, van Vlijmen H \& Karplus M. Evaluation of comparative protein modeling by MODELLER. Proteins 199523 318-326.

40 Laskowski RA, MacArthur MW, Moss DS \& Thornton JM. PROCHECK: a program to check stereo chemical quality of protein structures. Journal of Applied Crystallography 199326 283-291.

41 Laway BA, Goswami R, Singh N, Gupta N \& Seith A. Pattern of bone mineral density in patients with sporadic idiopathic hypoparathyroidism. Clinical Endocrinology 200664 405-409.

42 Bui M \& Liu Z. Simple allele-discriminating PCR for cost-effective and rapid genotyping and mapping. Plant Methods 200951.

43 Söderbergh A, Myhre AG, Ekwall O, Gebre-Medhin G, Hedstrand H, Landgren E, Miettinen A, Eskelin P, Halonen M, Tuomi T, Gustafsson J, Husebye ES, Perheentupa J, Gylling M, Manns MP, Rorsman F, Kämpe O \& Nilsson T. Prevalence and clinical associations of 10 defined autoantibodies in autoimmune polyendocrine syndrome type I. Journal of Clinical Endocrinology and Metabolism 200489 557-562.

44 Mizobuchi M, Ritter CS, Krits I, Slatopolsky E, Sicard G \& Brown AJ. Calcium-sensing receptor expression is regulated by glial cells missing-2 in human parathyroid cells. Journal of Bone and Mineral Research 200924 1173-1179.

45 Akiyama Y, Hosoya T, Poole AM \& Hotta Y. The gcm-motif: a novel DNA-binding motif conserved in Drosophila and mammals. PNAS $19969314912-14916$.

46 Zhao J, Hu Q, Chen Y, Luo S, Bao L \& Xu Y. A novel missense mutation in the paired domain of human PAX9 causes oligodontia. American Journal of Medical Genetics $2007 \mathbf{1 4 3}$ 2592-2597.

47 Sticht H \& Hashemolhosseini S. A common structural mechanism underlying GCMB mutations that cause hypoparathyroidism. Medical Hypotheses $2006 \mathbf{6 7} 482-487$.

48 van der Mey AG, Maaswinkel-Mooy PD, Cornelisse CJ, Schmidt PH \& van de Kamp JJ. Genomic imprinting in hereditary glomus tumours: evidence for new genetic theory. Lancet 19892 1291-1294.

49 Pantakani DV, Zechner U, Arygriou L, Pauli S, Sauter SM \& Mannan AU. Compound heterozygosity in the SPG4 gene causes hereditary spastic paraplegia. Clinical Genetics 200873 268-272.

50 Ben Yaou R, Toutain A, Arimura T, Demay L, Massart C, Peccate C, Muchir A, Llense S, Deburgrave N, Leturcq F, Litim KE, Rahmoun-Chiali N, Richard P, Babuty D, RécanBudiartha D \& Bonne G. Multitissular involvement in a family with LMNA and EMD mutations: role of digenic mechanism? Neurology 200768 1883-1894.
51 Goswami R, Ray D, Sharma R, Tomar N, Gupta R, Gupta N \& Sreenivas V. Presence of spondyloarthropathy and its clinical profile in patients with hypoparathyroidism. Clinical Endocrinology $200868258-263$.

52 Nishihara E, Nagayama Y, Amino N, Hishinuma A, Takano T, Yoshida H, Kubota S, Fukata S, Kuma K \& Miyauchi A. A novel thyrotropin receptor germline mutation (Asp617Tyr) causing hereditary hyperthyroidism. Endocrine Journal 200754 927-934.

53 Chang TY, Kuo HC, Hsiao KM \& Huang CC. Phenotypic variability of autosomal dominant myotonia congenita in a Taiwanese family with muscle chloride channel (CLCN1) mutation. Acta Neurologica Taiwanica 200716 214-220.

54 Sato H, Wada Y, Itabashi T, Nakamura M, Kawamura M \& Tamai M. Mutations in the pre-mRNA splicing gene, PRPF31, in Japanese families with autosomal dominant retinitis pigmentosa. American Journal of Ophthalmology 2005140 537-540.

55 Chin D, Speiser PW, Imperato-McGinley J, Dixit N, Uli N, David R \& Oberfield SE. Study of a kindred with classic congenital adrenal hyperplasia: diagnostic challenge due to phenotypic variance. Journal of Clinical Endocrinology and Metabolism $1998 \mathbf{8 3}$ 1940-1945.

56 Deneux C, Tardy V, Dib A, Mornet E, Billaud L, Charron D, Morel Y \& Kuttenn F. Phenotype-genotype correlation in 56 women with nonclassical congenital adrenal hyperplasia due to 21-hydroxylase deficiency. Journal of Clinical Endocrinology and Metabolism 200186 207-213.

57 Davies JL, Kawaguchi Y, Bennett ST, Copeman JB, Cordell HJ, Pritchard LE, Reed PW, Gough SCL, Jenkins SC, Palmer SM, Balfour KM, Rowe BR, Farrall M, Barnett AH, Bain SC \& Todd JA. A genome-wide search for human type 1 diabetes susceptibility genes. Nature 1994371 130-136.

58 Qi L, Hu FB \& Hu G. Genes, environment, and interactions in prevention of type 2 diabetes: a focus on physical activity and lifestyle changes. Current Molecular Medicine 2008 8 519-532.

59 Su D, Ellis S, Napier A, Lee K \& Manley NR. Hoxa3 and Pax1 regulate epithelial cell death and proliferation during thymus and parathyroid organogenesis. Developmental Biology 2001236 316-329.

60 Peters H, Neubüser A, Kratochwil K \& Balling R. Pax9-deficient mice lack pharyngeal pouch derivatives and teeth and exhibit craniofacial and limb abnormalities. Genes and Development 1998 12 2735-2747.

61 Kameda Y, Arai Y, Nishimaki T \& Chisaka O. The role of Hoxa3 gene in parathyroid gland organogenesis of the mouse. Journal of Histochemistry and Cytochemistry 200452 641-651.

62 Wurdak H, Ittner LM \& Sommer L. DiGeorge syndrome and pharyngeal apparatus development. Bioessays 200628 1078-1086.

Received 24 November 2009

Accepted 25 November 2009 